\title{
Die toekoms van Suid-Afrika se nasionale parke
}

Die Nasionale Parkeraad staan op die drumpel van een van die belangrikste mylpale van sy bestaan. Binne enkele weke sal 'n nuwe, werklik verteenwoordigende Raad van 18 lede die bestaande Raad vervang. So word die Nasionale Parkeraad dan ook ' $n$ wettige instelling van die Regering van Nasionale Eenheid.

Wat maak dié gebeurlikheid so besonders? Om dié vraag te kan beantwoord, is dit nodig om vlugtig in die geskiedenis van die Nasionale Parkeraad te delf.

Die Nasionale Parkeraad het in 1926 as 'n statutêre liggaam sy beslag gekry met die proklamering van die Nasionale Krugerwildtuin. Ander nasionale parke het gevolg: Kalahari-gemsbok Nasionale Park (1931), Addoolifant Nasionale Park (1931), Bontebok Nasionale Park (1931), Bergkwagga Nasionale Park (1937), Golden Gatehoogland Nasionale Park (1963), Tsitsikamma Nasionale Park (1964), Augrabies-waterval Nasionale Park (1966), Karoo Nasionale Park (1979), Wildernis Nasionale Park (1983), Weskus Nasionale Park (1985), Zuurberg Nasionale Park (1985), Vaalbos Nasionale Park (1986), Tankwa-Karoo Nasionale Park (1986), Knysna Nasionale Meergebied (1987), Marakele Nasionale Park (1988)en die Richtersveld Nasionale Park (1991).

Vandag is daar altesame 16 nasionale parke - Addo en Zuurberg is intussen gekonsolideer - wat' $n$ verskeidenheid biome en spesiediversiteit bewaar en namens alle SuidAfrikaners deur die Nasionale Parkeraad bestuur word.

Die Nasionale Parkeraad se bewaringsuksesse strek oor 'n verskeidenheid terreine, onder meer wildhervestiging, die beskerming van bedreigde spesies, die uitbreiding en konsolidering van nasionale parke, massainenting van spesies, jaarlikse lugsensusse, wildvangs, mariene, kus- en vleilandbewaring en hulpprojekte in ander Afrikastate. Die Parkeraad het ook reeds jare voor ander bewaringsorganisasies die belangrikheid van die aanwending van inligtingtegnologie in bewaring herken, en die GIS (Geografiese Inligtingstelsels) en ander rekenaargedrewe stelsels word dwarsdeur die organisasie gebruik.

In 1929 het slegs drie voertuie die Nasionale Krugerwildtuin besoek. Vandag, 66 jaar later, met meer as 650000 besoekers per jaar is dié vlagskip van Suid-Afrika se nasionale parke wêreldbekend as ons voorste ekobestemming. Die Nasionale Parkeraad het dus ook 'n voorste rolspeler in Afro-toerisme geword. In die ontwikkeling van sy toerisme-infrastruktuur is balans en vindingrykheid as die twee belangrikste riglyne gebruik: balans tussen bewaring en volhoubare benutting, en vindingryke maniere om nasionale parke deur staproetes en begeleide eko-avonture toeganklik te maak met die minsteomgewingsimpak.

Dit is in 'n neutedop die bekende, tradisionele prentjie van ons nasionale parke. Maar in 'n dekade of selfs langer het die winde van verandering wat soms stormagtig oor Suid-Afrika gewaai het, gelukkig ook die onbuigsame konsep van "omheinde" bewaringsgebiede laat verweer.

Nasionale parke was aanvanklik bewaringsgebiede waar alle mensverwante aktiwiteite wat nie met bewaring en volhoubare benutting vereenselwig kon word nie, taboe was. Met die toevoeging van die Wildernis Nasionale Park in 1983 het hierdie filosofie begin verander, aangesien die huiseienaars op die oewer van die Touwrivier ook in die parkbestuur in ag geneem moes word. Dit is verder uitgebrei deur die konsep van 'n ooreenkomspark waarvolgens die Postberg-natuurreservaat, wat in private besit gebly het, by die Weskus Nasionale Park ingelyf en as deel daarvan bestuur is. In nog 'n verdere stap het die Richtersveld Nasionale Park in 1991 Suid-Afrika se heel eerste volwaardige ooreenkoms nasionale park geword. Die grond bly die eiendom van die plaaslike gemeenskap wat hul nomadiese veeboerdery voortsit, maar die park word gesamentlik deur die Nasionale Parkeraad en die gemeenskap bestuur.

Grensdrade was al dikwels in die verlede 'n groot bron van irritasie, veral aan die wesgrens van die Nasionale Krugerwildtuin. In 'n verdere vergestalting van sy nuwe openheid, en in 'n gees van goeie buurmanskap, is die wesgrens tussen die Wildtuin en die aangrensende private natuurreservate in 1993 verwyder.

Nasionale parke is volksbesit wat deur die Nasionale Parkeraad bestuur word. Dit is dus belangrik dat alle SuidAfrikaners eienaarskap en 'n medeverantwoordelikheid vir ons natuurerfenis aanvaar. Onbekend maak onbemind is ongelukkig besonder relevant vir nasionale parke en die Nasionale Parkeraad het daarom die inisiatief geneem om beter verhoudings met landelike gemeenskappe binne en in die omgewing van nasionale parke te kweek. Nuwe projekte waarby veral buurgemeenskappe betrek word geniet die hoogste prioriteit. Tot onlangs het die klem hoofsaaklik op werkskepping geval, maar bure word by al hoe meer fasette van parkaktiwiteite betrek.

Armoede is een van die grootste bedreigings vir biodiversiteit en omgewingsintegriteit. Die Nasionale Parkeraad het daarom ' $n$ beleid aanvaar wat die behoeftes en aspirasies van parkbure by sy bewaringsopdrag insluit Dit is vir my organisasie so belangrik dat daar verlede jaar 'n Departement: Navorsing en Ontwikkeling geskep is om onder meer aan hierdie aspek aandag te gee. Forums is intussen gestig om kommunikasie tussen nasionale parke en hul bure te verbeter en die sosio-ekonomiese rol van die Nasionale Parkeraad uit te brei, veral op die gebied van werkskepping, aanleer van vaardighede, plaaslike entrepreneurskap en ontwikkelingsmoontlikhede buite nasionale parke. Dit sluit ook omgewingsbewustheidsprogramme in waartydens die buurgemeenskappe hul plaaslike nasionale park besoek.

Ondanks die jare van isolasie het die Nasionale Parkeraad sterk bande gesmee met die internasionale bewaringsgemeenskap, onder meer deur die IUCN (Die Wêreldbewaringsunie), die Verenigde Nasies se omgewingsprogram (UNEP), die Wêreldnatuurfonds (WWF), die Konvensie op Internasionale Handel in Bedreigde Spesies (CITES) en die Konvensie op die Bewaring van Vleilande van Internasionale Belang (RAMSAR). Danksy sy gevestigde infrastruktuur, tegniese kundigheid en goed gekwalifiseerde en ervare 
navorsingspersoneel het die Nasionale Parkeraad 'n sleutelrol in talle bewaringsprojekte elders in Afrika gespeel, onder meer in Madagaskar, die Ivoorkus en Malawi. Die Nasionale Parkeraad is ook nou betrokke by voortgesette pogings om oorgrens nasionale parke of vredesparke saam met buurlande tot stand te bring, by voorbeeld in die Kalahari, met Botswana, en met Mosambiek aan die oosgrens van die Nasionale Krugerwildtuin. 'n Soortgelyke park word in die verre noorde met Botswana en Zimbabwe in die vooruitsig gestel met die beoogde Vhembe/Dongola Nasionale Park.

Die Nasionale Parkeraad is toegewy aan Suid-Afrika se Heropbou- en Ontwikkelingsprogram, ordelike verandering, demokrasie en regstellende aksie. Die onlangse herstrukturering van die organisasie, die integrasie van swart werknemers op alle vlakke, maar veral ook in die bestuur van die organisasie, en die transformasieproses wat volstoom aan die gang is, het reeds 'n metamorfose tot gevolg gehad.

Onder die rentmeesterskap van die Nasionale Parkeraad het nasionale parke ontwikkel van omheinde bewaringsgebiede wat angsvallig bewaak is - soos versinnebeeld deur die Nasionale Krugerwildtuin in 1926 - tot nasionale skatte wat aan alle Suid-Afrikaners behoort en 'n gees van welwillendheid, konsultasie en versoening weerspieël in gesamentlike parkbestuur en sosioekonomiese ondernemings. In bewaringsterme het die Nasionale Parkeraad tred gehou met verandering, om nasionale parke nie net teen die mens nie, maar veral ook ter wille van die mens te beskerm.

Die Nasionale Parkeraad het deur tydige stappe die toekomstige voortbestaan van Suid-Afrika se nasionale parke verseker. Met die bekendmaking van die nuwe Raad sal ons finaal die drumpel oorsteek en die ou bedeling agterlaat.

My eie missie en ideaal vir die NASIONALEPARKE van Suid-A frika is dat hulle die "TROTS EN VREUGDE" moet word van elke Suid-Afrikaner-parke moet deel wees van nasiebou, 'n nasie wat omgee vir sy natuurskatte.

G.A.ROBINSON Nasionale Parkeraad 